Technical Note

\title{
Effects of the 12 May 2021 Geomagnetic Storm on Georeferencing Precision
}

\author{
Juan Carlos Valdés-Abreu ${ }^{1,2} \mathbb{D}$, Marcos A. Díaz ${ }^{1,2, * \mathbb{D}}$, Juan Carlos Báez ${ }^{3} \mathbb{D}$ and Yohadne Stable-Sánchez ${ }^{1} \mathbb{D}$ \\ 1 Space and Planetary Exploration Laboratory (SPEL), Faculty of Physical and Mathematical Sciences, \\ University of Chile, Av. Tupper 2007, Santiago 8370451, Chile; juanvaldes@ug.uchile.cl (J.C.V.-A.); \\ spel@ing.uchile.cl (Y.S.-S.) \\ 2 Department of Electrical Engineering, Faculty of Physical and Mathematical Sciences, University of Chile, \\ Av. Tupper 2007, Santiago 8370451, Chile \\ 3 National Seismological Center, Faculty of Physical and Mathematical Sciences, University of Chile, \\ Av. Beaucheff 1225, Santiago 8370583, Chile; jcbaez@csn.uchile.cl \\ * Correspondence: mdiazq@ing.uchile.cl
}

check for updates

Citation: Valdés-Abreu, J.C.; Diaz, M.A.; Báez, J.C.; Stable-Sánchez, Y.

Effects of the 12 May 2021

Geomagnetic Storm on

Georeferencing Precision. Remote Sens. 2022, 14, 38. https://doi.org/ $10.3390 /$ rs14010038

Academic Editors: Carlo Scotto and Marco Anzidei

Received: 1 November 2021 Accepted: 4 December 2021 Published: 23 December 2021

Publisher's Note: MDPI stays neutral with regard to jurisdictional claims in published maps and institutional affiliations.

Copyright: (c) 2021 by the authors. Licensee MDPI, Basel, Switzerland. This article is an open access article distributed under the terms and conditions of the Creative Commons Attribution (CC BY) license (https:// creativecommons.org/licenses/by/ $4.0 /$ )

\begin{abstract}
In this work, we present the positioning error analysis of the 12 May 2021 moderate geomagnetic storm. The storm happened during spring in the northern hemisphere (fall in the south). We selected 868 GNSS stations around the globe to study the ionospheric and the apparent position variations. We compared the day of the storm with the three previous days. The analysis shows the global impact of the storm. In the quiet days, $93 \%$ of the stations had $3 \mathrm{D}$ errors less than $10 \mathrm{~cm}$, while during the storm, only $41 \%$ kept this level of accuracy. The higher impact was over the Up component. Although the stations have algorithms to correct ionospheric disturbances, the inaccuracies lasted for nine hours. The most severe effects on the positioning errors were noticed in the South American sector. More than $60 \%$ of the perturbed stations were located in this region. We also studied the effects produced by two other similar geomagnetic storms that occurred on 27 March 2017 and on 5 August 2019. The comparison of the storms shows that the effects on position inaccuracies are not directly deductible neither from the characteristics of geomagnetic storms nor from enhancement and/or variations of the ionospheric plasma.
\end{abstract}

Keywords: global navigation satellite system; geomagnetic storms; global positioning system; precise point positioning; total electron content; rate of change of the tec index

\section{Introduction}

The tendency to incorporate autonomous or tele-operated systems in certain industries around the globe requires careful analysis over the performance of the technology that supports this activity. One of the key elements in those systems is the global navigation satellite system (GNSS), which allows the geolocation of a receiver almost anywhere in the world. However, GNSS as a radio-link-based system can be perturbed by variations in the ionosphere. In particular in Chile, mining, fishing, and agriculture activities are relevant economic sectors in Chile that are exploring the migration to a more teleoperated/autonomous operation. Due to this requirement, it is imperative to study the robustness of the GNSS systems along the country, in particular when geomagnetic storms are produced.

One of the most important drivers of ionospheric variations at a global scale is solar activity. During a geomagnetic storm, the ionosphere can be greatly perturbed through the Sun-solar wind-magnetosphere-ionosphere-atmosphere coupling process. Perturbations in the ionosphere, in particular electrons, can produce disturbances in space-based technology and their products such as communication disruptions and imprecision in the positioning estimation of global navigation satellite system (GNSS). The enhancement or oscillations in the ionospheric electron content influence the signal between a 
satellite (GNSS/communication) and a receiver. In particular, the signal delay is affected differently depending on the signal frequency, resulting in a reduction in the accuracy of multifrequency GNSS receivers.

A geomagnetic storm is a major temporary disturbance in the Earth's magnetic activity and is associated with solar activity, e.g., coronal mass ejection (CME) and high-speed solar wind stream (HSS) [1]. When there is greater solar activity, geomagnetic storms are mainly generated by CME, while during moments of less solar activity, it is the coronal holes that have a dominant effect [2]. Geomagnetic storms occur when there is a large sudden change in the solar wind dynamic pressure at the magnetopause [3]. The distinctive characteristic of a geomagnetic storm is a clear decrease in the horizontal intensity of the magnetic field [3]. Geomagnetic storms can be usually divided into three main phases: initial, main, and recovery [4-6]. The geomagnetic storms are detected prior to the ionospheric disturbances and to the decrease in positioning estimation.

Different geomagnetic indices are used to characterize geomagnetic storms such as the disturbance storm time (Dst) index, geomagnetic disturbance (Kp), averaged geomagnetic activity (Ap) (based on data from a set of specific Kp stations), and the auroral electrojet (AE) index, where the Dst-index is associated with the effects on the equatorial region, the $\mathrm{Kp}$-index to the midlatitudes, and the AE-index at high latitudes since it characterizes the intensity of ionospheric currents during magnetic storms and substorms activity $[7,8]$. The Dst-index has been used historically to characterize the severity of a geomagnetic storm. Depending on the Dst value, the storms are usually classified in ranges such as weak $(-30 \mathrm{nT}$ and $-50 \mathrm{nT})$, moderate $(-50 \mathrm{nT}$ and $-100 \mathrm{nT})$, intense $(-100 \mathrm{nT}$ and $-200 \mathrm{nT})$, very intense $(-200 \mathrm{nT}$ and $-350 \mathrm{nT})$, and great (Dst below $-350 \mathrm{nT})[3,4,9,10]$. Furthermore, the Kp-index is based on $3 \mathrm{~h}$ measurements from ground-based magnetometers around the world (https: / / www.spaceweatherlive.com/, accessed on 3 December 2021). The storms are usually classified as minor (G1) with a $\mathrm{Kp}=5$; moderate (G2) with a $\mathrm{Kp}=6$; strong (G3) with a $\mathrm{Kp}=7$; severe (G4) with $\mathrm{Kp}=8$, and extreme (G5) with Kp $=9$ (https://www.swpc.noaa.gov/noaa-scales-explanation, accessed on 3 December 2021) [10,11]. The Ap-index provides a daily average level for geomagnetic activity. The Kp-value converts a linear scale called the a-index. The average from eight daily a-values gives us the Ap-index of a certain day. Thus, high levels of geomagnetic activity have a higher daily Ap-value (https://www.swpc.noaa.gov/noaa-scales-explanation, accessed on 3 December 2021) [11].

The AE-index was originally introduced by Davis and Sugiura [7] as a measure of global electrojet activity in the auroral zone. The AE-index is derived from measurements of the horizontal components (H-components) of the Earth's magnetic field obtained from a series of observatories along the auroral zone in the northern hemisphere $[7,8,12]$. The AE-index is estimated as $\mathrm{AE}=\mathrm{AU}-\mathrm{AL}$, where $\mathrm{AU}$ and $\mathrm{AL}$ indexes are obtained from the upper and lower envelope of the superposed H-components [7,12]

The geomagnetic storms can also be identified by various other parameters such as the symmetric disturbance of the magnetic field H (SYM-H); the interplanetary electric field (IEF); and the interplanetary magnetic field (IMF), where IMF-Bz is the most important parameter for the study of geomagnetic storms, as the energy input into the magnetosphere, depends on Bz orientation and its magnitude [13]. Although these indexes provide extra information regarding the space conditions, some of them are related to the Dst-index. For instance, a relationship has been shown between Dst and Bz [14].

The response of the ionosphere to geomagnetic induced disturbances is known as ionospheric storm $[15,16]$. Ionosphere plasma density is mainly determined by the chemistry/composition, transport due to electric field, transport due to neutral wind, and transport due to ambipolar diffusion. During geomagnetic storms, the variations of chemistry or the thermospheric composition, and the interaction with the neutrals (neutral wind) [17,18], and/or variations of electric field and ambipolar diffusion [19] are the final cause that alters the ionosphere plasma density. Nevertheless, the response of the ionosphere during a geomagnetic storm is complex and difficult to predict accurately, and the physical nature of 
many underlying mechanisms needs a better understanding to obtain precise forecasting of its behavior based on geomagnetic storms parameters [20]. In addition, the effects of these physical processes on the ionosphere have also been reported to vary with solar activity, storm intensity, storm duration, season, location, local time, and altitude of the observing station, which increases the forecast uncertainties [6,21-27]. For instance, Tsurutani et al. [28] and Mannucci et al. [29] have found that the response of the ionosphere to geomagnetic activity depends on the season of the year in which that portion of the ionosphere is located [30,31].

The ionospheric plasma density can be estimated by estimating the ionospheric electron density. Thus, it is the determining variable for investigation of the spatial and temporal variations in the ionosphere. The total electron content (TEC), which can be estimated from double-frequency GNSS receiver data, is used to study the ionospheric response during ionospheric storms $[1,3,9,20,32,33]$. The TEC is defined as the integral of the electron density from the ground height up to the ceiling height, i.e., the height of the transmitting satellite or infinity. Since the contribution to the TEC usually comes from low orbital altitudes (below $1000 \mathrm{~km}$ ), then, vertical TEC (VTEC) is obtained from Slant TEC (STEC) at the ionospheric pierce point (IPP) at an altitude of $350 \mathrm{~km}$. Another relevant ionospheric index used to study ionospheric variations is the rate of change of the TEC index (ROT). ROT is calculated in a temporal window. ROTI is defined as the standard deviation of ROT. It describes the small-scale variability of the line-of-sight electron content resulting from the ionosphere and plasmasphere. The total electron content (TEC) maps, together with other indexes derived from TEC, are used to estimate the locations and time where larger signal delays in GNSS receivers might produce higher positioning errors.

Several TEC disturbances studies have been conducted in recent years [13,32-39]. However, they have mainly focused on TEC and in the northern hemisphere. Nevertheless, some studies of TEC have been conducted with special focus on the South Atlantic Anomaly area [40-48]. Besides these works and some other exceptions (e.g., [49]), there is a lack of studies in the southern hemisphere. In addition, all the abovementioned works did not study the effect of TEC on positioning error.

Although the position estimation of a GNSS receiver depends on TEC, for several reasons (location, correction algorithms, etc.), perturbations on TEC are not reflected in a simple manner over the position accuracy. Therefore, it is relevant to study the actual performance of the positioning estimation of GNSS receiver during geomagnetic storms. To evaluate the position error during geomagnetic storms, the precise point positioning (PPP) method is used. PPP is a method that performs efficient computation to determine high-quality coordinates. It uses a single receiver processing strategy for GNSS [50,51]. PPP does not require any additional data from a reference station and can provide a solution from a centimeter to decimeter level of positional accuracy both in static and kinematic modes [50,52]. For these reasons, PPP has become the predominant positioning technique [50]. Many free PPP online services are available, such as the Automatic Precise Positioning Service (APPS) of the Global Differential GPS (GDGPS) System (https://apps.gdgps.net/, accessed on 3 December 2021), the GNSS Analysis and Positioning Software (GAPS-PPP) (http://gaps.gge.unb.ca/, accessed on 3 December 2021), the magicGNSS solution (magicGNSS) (https:/ / magicgnss.gmv.com/, accessed on 3 December 2021), and the Precise Point Positioning of Canadian Spatial Reference System (CSRS-PPP) (https:/ / webapp.geod.nrcan.gc.ca/geod/tools-outils/ppp.php, accessed on 3 December 2021) [53-55]. The CSRS-PPP service is one of the most used PPP online services in the field, and we use this service in this work to obtain the PPP estimation.

More recent studies have presented TEC disturbances produced by geomagnetic storms including GNSS position errors (PPP). These latest studies of geomagnetic storms and errors in GNSS positioning have focused on storms of the Solar Cycle 24. A summary of these studies can be found in Table 1 . 
Table 1. Example studies related to the impact of geomagnetic storms of Solar Cycle 24 (SC-24) on kinematic GPS positioning.

\begin{tabular}{ccccccc}
\hline $\begin{array}{c}\text { Geomagnetic } \\
\text { Storm }\end{array}$ & $\begin{array}{c}\text { Dst } \\
\text { [nT] }\end{array}$ & Kp & $\begin{array}{c}\text { AE } \\
\text { [nT] }\end{array}$ & $\begin{array}{c}\text { Stations } \\
\mathbf{N}^{\circ}\end{array}$ & Kinematic PPP & Method \\
\hline 7 January 2015 [56] & -99 & $6^{+}$ & 2031 & 3 & GIPSY-OASIS & ROTI \\
17 March 2015 [57] & -223 & $8^{-}$ & 2298 & $\sim 500$ & GPS PPP Model & ROTI \\
17 March 2015 [58] & -223 & $8^{-}$ & 2298 & 15 & gLAB software & DVTEC, TIDs \\
22, 23 June 2015 [59] & -204 & $8^{+}$ & 2698 & 5172 & GAMP software & Spread-F, S4 \\
20 December 2015 [57] & -155 & $7^{-}$ & 1946 & $\sim 500$ & GPS PPP Model & ROTI \\
27 March 2017 [57] & -74 & $6^{+}$ & 1505 & $\sim 500$ & GPS PPP Model & ROTI \\
8 September 2017 [60] & -124 & $8^{+}$ & 2677 & $\sim 700$ & RTKLIB package & ROTI \\
\hline
\end{tabular}

Table 1 shows that there are not many studies related to the impact over the GNSS positioning accuracy of moderate geomagnetic storms. In a recent study, it was shown that the storm of 5 August 2019 , which can be categorized as moderate (Dst peak $=-53 \mathrm{nT}$, $\mathrm{Kp}=5^{+}, \mathrm{AE} \sim 1000 \mathrm{nT}$ ), had strong effects on TEC [61]. However, this work did not study the positioning accuracy of GNSS stations. The only study of the positioning error that considers a moderate geomagnetic storm was presented by Luo et al. [57] (see Table 1). Luo et al. analyzed three geomagnetic storms in Solar Cycle 24. For the analysis, they used 17 March 2017 as a reference day for all the analyzed storms, which is a quiet day $\left(\mathrm{Kp}=1^{+}\right)$. This work neither analyzes the conditions on the previous/posterior days for each storm nor removes the noise sources, such as other geophysical events (earthquakes) or interference from other radio emissions. In addition, in this work, the root means square (RMS) statistics per component (North, East, and Up) were obtained per latitude (high-, mid-, and low-). Thus, the reported 3D RMS was calculated with the components that combine different stations located at a similar latitude range.

In this work, we present the positioning error analysis of the 12 May 2021 geomagnetic storm (Dst peak $=-61 \mathrm{nT}, \mathrm{Kp}=7, \mathrm{AE} \sim 1500 \mathrm{nT}$ ), which can be classified as moderate in terms of Dst but strong in terms of Kp. Although the study is at a global scale, unlike previous studies, we focus on the southern sector of America due to the large number of GNSS stations now available in this part of Latin America. We studied the spatial and temporal dependence of the higher errors estimated in the GNSS receivers for this storm. We also studied the time needed for some geodesic-quality GNSS stations to reduce the positioning error thanks to the algorithms that detect and correct the effects of TEC disturbances. By using three stations, one close to Madrid (Spain) and the other two in Chile (one close to Santiago and a second one $400 \mathrm{~km}$ south of it), we studied the effects on the positioning accuracy for two other moderate storms (27 March 2017 and 5 August 2019) to verify the methodology used in the 12 May 2021 study.

\section{Materials and Methods}

In this section, we describe the used data and processing procedure. The proposed procedure also includes analyzing the geophysical and geomagnetic conditions close to 12 May 2021.

\subsection{Estimation of the Ionospheric Total Electron Content}

The slant TEC (STEC) and vertical TEC (VTEC) data were obtained from GNSS measurements based on dual-frequency signals $f_{1}$ and $f_{2}$. Then, STEC and VTEC were calculated using the program GPS-TEC from receiver independent exchange format (RINEX) files [62] (http:/ / seemala.blogspot.com/, accessed on 3 December 2021). In this work, VTEC values corresponding to satellite cut-off elevation angle $30^{\circ}$ at $350 \mathrm{~km}$ altitude were selected to minimize possible errors. The temporal VTEC estimates were released every $30 \mathrm{~s}$. The TEC values were corrected from the satellite and receiver bias using the data obtained 
from AIUB Data Center of Bern University in Switzerland (ftp:/ / ftp.aiub.unibe.ch/CODE/, accessed on 3 December 2021).

The RINEX files were obtained from 868 GNSS stations (Figure 1), taked from: the International GNSS service (IGS) stations; the Chilean network of GNSS receivers operated by the National Seismological Center at University of Chile (CSN in Spanish); the Argentine Continuous Satellite Monitoring Network (RAMSAC in Spanish) [63]; the Brazilian Network for Continuous Monitoring of the Institute of Brazilian Geography and Statistics (IGBE in Portuguese); and the Crustal Dynamics Data Information System (CDDIS) of the National Aeronautics and Space Administration (NASA); University NAVSTAR Consortium (UNAVCO); the Geoscience Australia; and the African Geodetic Reference Frame (AFREF).

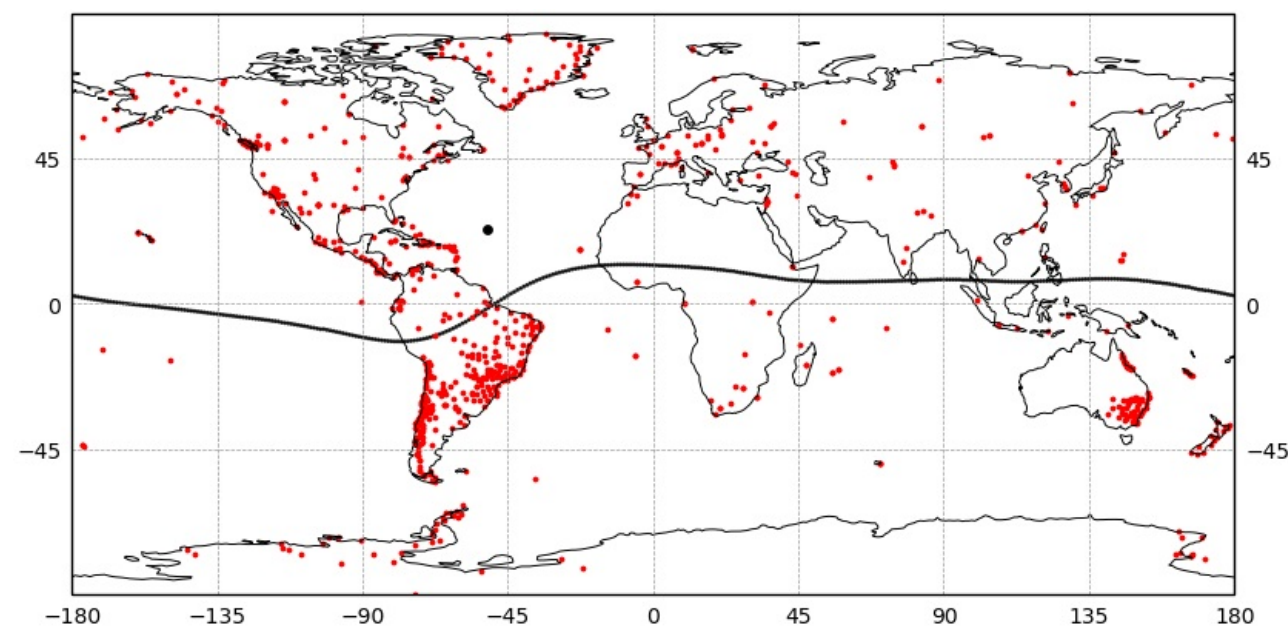

Figure 1. 868 GNSS receivers (red dots) used in present work. The Sun at 14.50 UT (black dot) on 12 May 2021, and the magnetic equator (black line).

In addition, the differential of VTEC (DVTE) in TECu and the percentage changes in VTEC (\%DVTEC) were studied. These parameters are used in the analysis of ionospheric disturbances, defined as the relative variation of VTEC, epoch by epoch, with respect to the mean value (in time) of $\overline{V T E C}$ as shown in Equations (1) and (2) [3].

$$
\begin{aligned}
& D V T E C_{t}=V T E C_{t}-\overline{V T E C_{t}} \\
& \% D V T E C_{t}=\frac{D V T E C_{t}}{\overline{V T E C_{t}}} \cdot 100
\end{aligned}
$$

where $t$ represents the epoch and $\overline{V T E C}$ is calculated by averaging the values of VTEC for the reference DoYs 129, 130, and 131.

Ionospheric TEC Maps

We used the ordinary Kriging interpolation technique [64] to map the estimation of the VTEC at each ionospheric pierce point (IPP). We selected this interpolation technique to fill in the data gap of the global ionosphere TEC map and the inhomogeneous sparsity of GNSS receivers [65-67]. We performed the ordinary Kriging interpolation in Python with the package Kriging. The documentation for the package can be found in https:/ / github.com/ERSSLE/ordinary_kriging (accessed on 3 December 2021).

\subsection{ROT and ROTI}

Rate of change of the TEC Index (ROTI) is defined as the standard deviation of the rate of TEC (ROT). It is used in the detection and investigation of occurrences of ionospheric 
irregularities. ROTI was estimated by dual-frequency GNSS data with the time interval of 5 min by using Equation (3) [68-72]:

$$
R O T I=\sqrt{\left\langle R O T^{2}\right\rangle-\langle R O T\rangle^{2}}
$$

where $\langle\cdot\rangle$ represents the temporal average. The ROT and ROTI values are typically expressed in units of TECu/min. ROT is defined as the TEC variation rate of two successive epochs as stated in Equation (4) [68-71]:

$$
R O T=\frac{S T E C_{t}^{i}-S T E C_{t-1}^{i}}{k_{t}-k_{t-1}}
$$

where $k, t$, and $i$ represent the GPS time, the epoch, and the number of observation satellites, respectively.

According to Liu et al. [73], the ROTI value can be divided into three groups: weak, if $0.25 \leqslant$ ROTI $<0.5$; moderate, if $0.5 \leqslant \mathrm{ROTI}<1$; and strong, if ROTI $\geqslant 1$.

\subsection{Apparent Position Variation Using Precise Point Positioning}

The RINEX files of 868 GNSS stations were processed in the postprocessing kinematic precise point positioning with ambiguity resolution (PPP-AR) mode in the Precise Point Positioning of Canadian Spatial Reference System (CSRS-PPP) online service (https:/ / webapp.geod.nrcan.gc.ca/geod/tools-outils/ppp.php, accessed on 3 December 2021) [53]. The CSRS-PPP provides centimeter-level estimations with converged float solutions [53-55,74]. The CSRS-PPP returns to the user a processing report via email.

Usually, the report provides a different reference value for different days. We process the data to have an equal reference for all the used data to facilitate the evaluation of the position-variation time series. At each of the 868 stations, we also apply the common noise filter to correct the time series of the North, East, and Up components (Equation (5)). Then, we estimate the $3 \mathrm{D}$ resultant.

$$
C A P d o y_{t}=A P d o y_{t}-R P_{t}
$$

where $t$ is the epoch, CAPdoyt is the corrected apparent position, APdoyt is the apparent uncorrected position, and $R P_{t}$ is the reference position. We use $\overline{A P}$ from reference DoYs 129,130 , and 131 to calculate $R P_{t}$.

At each of the 868 stations, the maximum error was calculated for eight days and with time windows of $15 \mathrm{~min}$. Subsequently, the percentage of stations in East, North, Up, and 3D position errors intervals was calculated.

\subsection{Geophysical and Geomagnetic Conditions}

The geomagnetic data were downloaded from the World Data Center (WDC) for Geomagnetism, Kyoto (http:/ /wdc.kugi.kyoto-u.ac.jp/wdc/Sec3.htm, accessed on 3 December 2021) [75]; OMNIWeb Plus Data Documentation (https: / / omniweb.gsfc.nasa.gov/ form/dx1.html, accessed on 3 December 2021); and GFZ Helmholtz Centre Potsdam (https:/ / www.gfz-potsdam.de/en/kp-index/, accessed on 3 December 2021) [76].

On 12 May 2021 (DoY 132), a moderate geomagnetic storm (G3) took place with a $\mathrm{Kp}$-index $\geqslant 4$ from 6 UT. The maximum Kp-index of 7 was sustained between 12 and 15 UT. The Kp-index went below 3 after the 18 UT.

The geomagnetic storm started on the DoY 132. Its initial phase started at $\sim 6$ UT and lasted $\sim 6 \mathrm{~h}$. During this period, the Dst-index slowly decreased. The main phase of the storm started at $\sim 12.4 \mathrm{UT}$ and lasted for $\sim$ one hour. In the storm main phase, the Dst-peak of $-61 \mathrm{nT}$ was reached at $14 \mathrm{UT}$. At that time, the geomagnetic storm recovery phase began. The Dst-index went over $-30 \mathrm{nT}$ at $\sim 23$ UT on the DoY 132 (see Figure 2b). We were unable to obtain the raw data of the AE-index, but it is possible to observe the behavior of this index in the graphical display of the data on the website of the WDC for Geomagnetism, Kyoto 
(http: / / wdc.kugi.kyoto-u.ac.jp/ae_realtime/202105/index_20210512.html, accessed on 3 December 2021). In that image, it is possible to see an intensification of the AE-index with two peaks $\sim 1500 \mathrm{nT}$ between 12 and $16 \mathrm{UT}$.

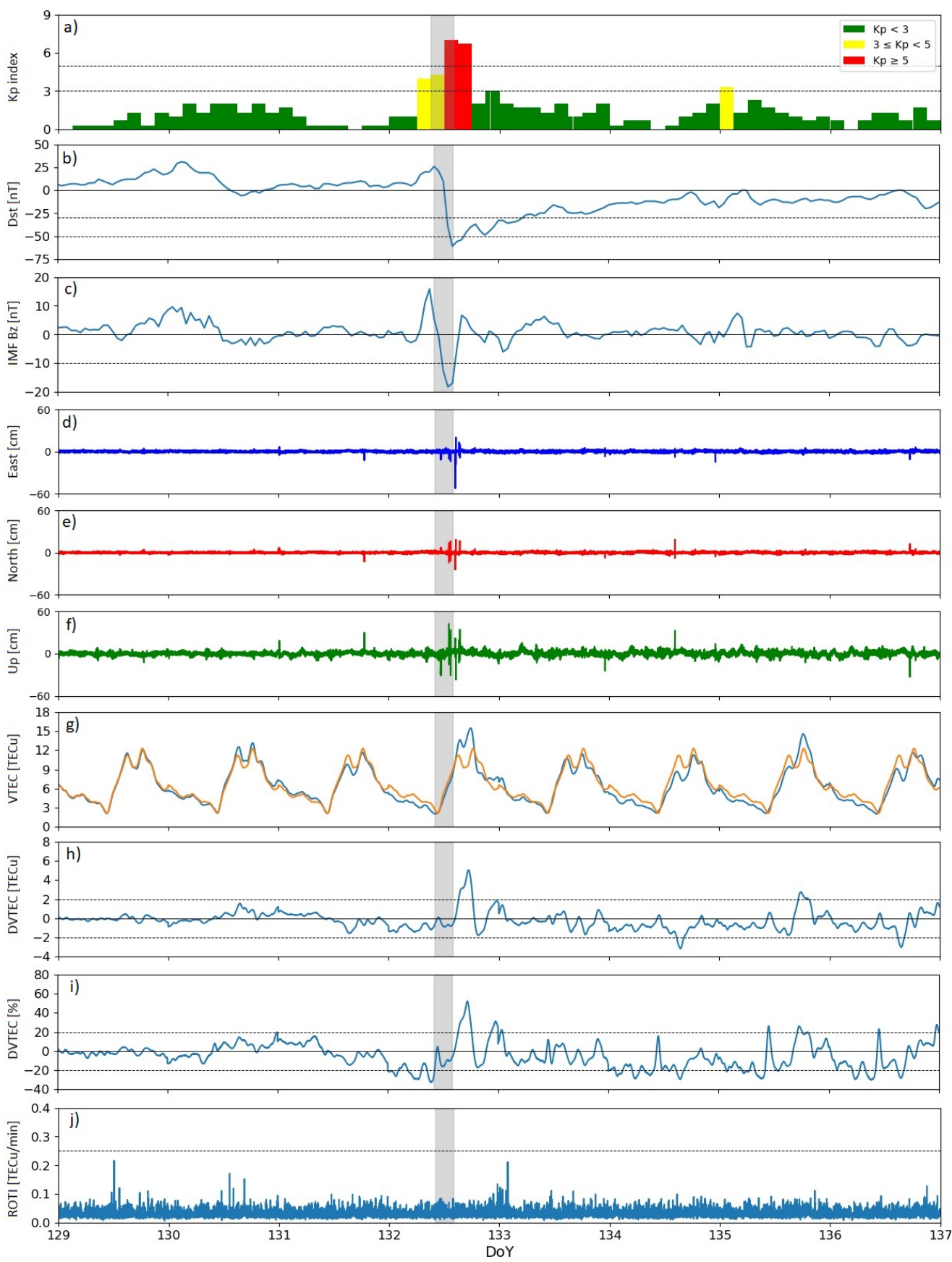

Figure 2. Panels (a) (Kp-index), (b) (Dst-index), and (c) ( $\mathrm{Z}$ component of interplanetary magnetic field, IMF Bz) show the different indexes that characterize the geomagnetic conditions. Panels (g-j) present the different TEC variations related indexes (VTEC, DVTEC, \%DVTEC, and ROTI). The panels $(\mathbf{d}-\mathbf{f})$ display the positioning error of each component in the vita station, Vegas de Itata, Chile $\left(36.42^{\circ} \mathrm{S}, 72.86^{\circ} \mathrm{W}\right)$. The orange line represents $\overline{V T E C}$ calculated with the reference days (DoYs 129,130 , and 131). (g) We represent the $\overline{V T E C}$ in all the studied DoYs to compare it with the VTEC of each of the days (blue line).

The IMF Bz was below -10 nT between 12 and 15 UT on the day of the storm (DoY 132). The minimum Bz of $-18.3 \mathrm{nT}$ was reached at $13 \mathrm{UT}$. According to the Gonzalez and 
Tsurutani criteria [2], this event can be classified as a geomagnetic storm since it was caused by an interplanetary magnetic field $\mathrm{Bz} \leq-10 \mathrm{nT}$ that lasted more than $3 \mathrm{~h}$ (see Figure 2c).

The geomagnetic conditions were generally quiet between 9 and 11 of May 2021 (DoYs 129 and 131), where the Dst-index was predominantly positive, and the maximum Kp-index was 2 (see Figure 2a).

\subsection{Possible Earthquakes Perturbations}

We reviewed the occurrence of earthquakes (EQs) around the world with moment magnitudes over $5 \mathrm{Mw}$ and depth less than $70 \mathrm{~km}$ between the 9 and 17 of May 2021 (DoYs 129 to 137). The data were obtained from https:/ / earthquake.usgs.gov/earthquakes / search/ (accessed on 3 December 2021). Five strong EQs (6-6.9 Mw) and twenty moderate EQs (5-5.9 Mw) occurred in this analyzed period. However, none of them produced noticeable effects on TEC during the geomagnetic storm period. The differential TEC was analyzed, taking care of the potential minor effects in the other days of the analyzed period.

\section{Results}

In this section, we present the main results obtained after applying the methodology described in the previous section to the 868 stations.

First, we isolated the period of time to analyze. We focused the study between 9 May and 17 May 2021 (DoY 129 to 137). Figure 2 presents an example of the signals analyzed for this work. We calculated VTEC, DVTEC, \%DVTEC, and ROTI as described in the previous section. These variables can be seen in panels $(\mathrm{g}-\mathrm{j})$ of Figure 2 , respectively, for a sample station, the Vegas de Itata station (known as vita station) located in Chile $\left(36.42^{\circ} \mathrm{S}\right.$, $72.86^{\circ} \mathrm{W}$ ). Then, by using the VTEC and the PPP-AR method (see Section 2.3), we were able to obtain the apparent position variation. In panels (d) to (f) in Figure 2, we present the root mean square (RMS) time series of the apparent position, after correcting using the common noise filter (see Equation (5)), per each component (East, North, and Up) also for the vita station. It is clear in the image that the period of the storm is the period with the larger uncertainties in the position estimation.

From each station data, we can estimate the VTEC over each station during the period of the geomagnetic storm (14.50-14.75 UT) on 12 May 2021 as shown in Figure 3a. By using the ordinary Kriging interpolation, as described in Section 2.1, it is possible to obtain filled-in VTEC maps for the geomagnetic storm day (Figure 3c) and for the averaged VTEC $(\overline{V T E C}) . \overline{V T E C}$ is calculated with the VTEC of the previous days to the geomagnetic storm, DoYs 129, 130, and 131 (Figure 3b). Figure 3d,e show the differential VTEC (DVTEC) and perceptual DVTEC (\%DVTEC) for the time of the geomagnetic storm, respectively, which are obtained by using Equations (1) and (2) with the data presented in (Figure 3b,c). From these figures, it is possible to notice that the South American sector is one of the most affected in terms of VTEC enhancement.

Since this study focuses on the positioning accuracy of the stations during a moderated storm, we estimate the PPP-AR as described in Section 2.3. Figure 4 (left panel) and Figure 5 (left panel) show different 3D positioning error maps for various times, obtained using the CSRS-PPP service. The reports provided by CSRS had different reference values for each of the eight days requested. This provoked that more than $5 \%$ of the stations had baselines with differences over $100 \mathrm{~cm}$, such as: lovj $\left(67.89^{\circ} \mathrm{N}, 34.62^{\circ} \mathrm{E}\right), \operatorname{novm}\left(55.03^{\circ} \mathrm{N}\right.$, $\left.82.91^{\circ} \mathrm{E}\right)$, ieng $\left(45.02^{\circ} \mathrm{N}, 7.64^{\circ} \mathrm{E}\right), \operatorname{mdvj}\left(56.02^{\circ} \mathrm{N}, 37.21^{\circ} \mathrm{E}\right), \operatorname{meco}\left(-29.18^{\circ} \mathrm{S},-58.08^{\circ} \mathrm{W}\right)$, csom $\left(-52.78^{\circ} \mathrm{S},-69.22^{\circ} \mathrm{W}\right)$ stations. Therefore, we processed the data to have an equal reference for all stations to facilitate the evaluation of the position variation time series.

After calculating the apparent position variation for each station in the time period of the geomagnetic storm (DoY 132, 14.50-14.75 UT), we quantified the number of stations around the world that had errors that fell in certain intervals $(<5 \mathrm{~cm},[5-10] \mathrm{cm},[10-20] \mathrm{cm}$, [20-40] cm, [40-60] cm, [60-100] cm and $>100 \mathrm{~cm}$ ). It is important to highlight that the PPP-AR procedure includes the use of a common noise filter (see Equation (5)). Without the filter, we had periods of time where certain GNSS stations consistently had very high errors 
even during quiet days. The results of the classification of the stations by their positioning errors is presented in Table 2. Each column on the table represents the percentage of stations with errors in a certain interval per each positioning component as well as the combination of these components in the 3D parameter. Each component uses two contiguous columns in Table 2, one with the percentages obtained for the average of the previous quiet days (e.g., North) and another with the percentage measured during the day and period of the geomagnetic storm (e.g., North gs). In this table, the percentage of the stations per interval for East, North, Up, and 3D position errors were obtained using the data from the total 868 GNSS stations around the globe we had available.

In Table 2, we present a snapshot of the errors focused on the geomagnetic storm time. Nevertheless, we also present a temporal evolution of the percentage of the stations with positioning errors over a certain threshold per component for the total of the available stations around the world in Figure 6. From this figure, it is possible to notice that the main errors are concentrated over the mid-day of the DoY 132, which is the geomagnetic storm period.

It is possible to notice from the TEC (e.g., Figure 3) and the derived PPP-AR (Figures 4 (left panel), and 5 (left panel)) data that there is a region where the errors are more severe during the geomagnetic storm (DoY 132, 14.50-14.75 UT). This region is South America. In South America are located 325 stations of the 868 total available GNSS stations ( $\sim 37 \%)$. In Table 3, we present similar results compared to in Table 2 but with the 325 stations of this region. However, there is no other localized area in which we can detect strong variations. The other perturbed stations are distributed around the world. For this reason, we concentrated this study in the South American sector.

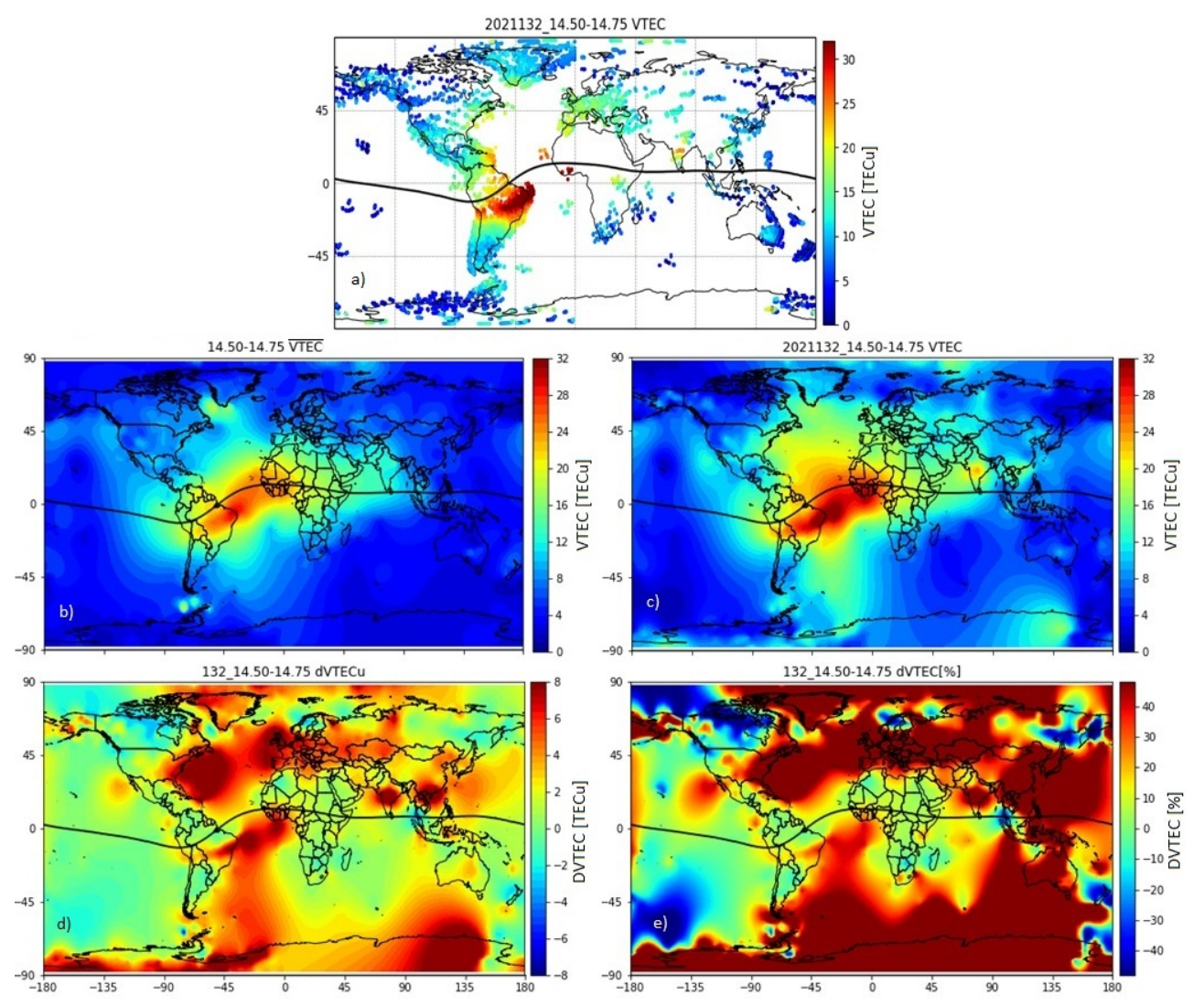

Figure 3. Ionospheric TEC maps using the Kriging interpolation method during the maximum apparent variation of position (between 14.50 and 14.75 UT). (a) VTEC at each IPP on the geomagnetic storm day. (b) $\overline{V T E C}$ is obtained by averaging the VTEC values of DoYs 129, 130, and 131, for 2021. (c) VTEC of geomagnetic storm day. (d) DVTEC is VTEC of geomagnetic storm day minus $\overline{V T E C}$. (e) The percentage changes in VTEC, \%DVTEC. 

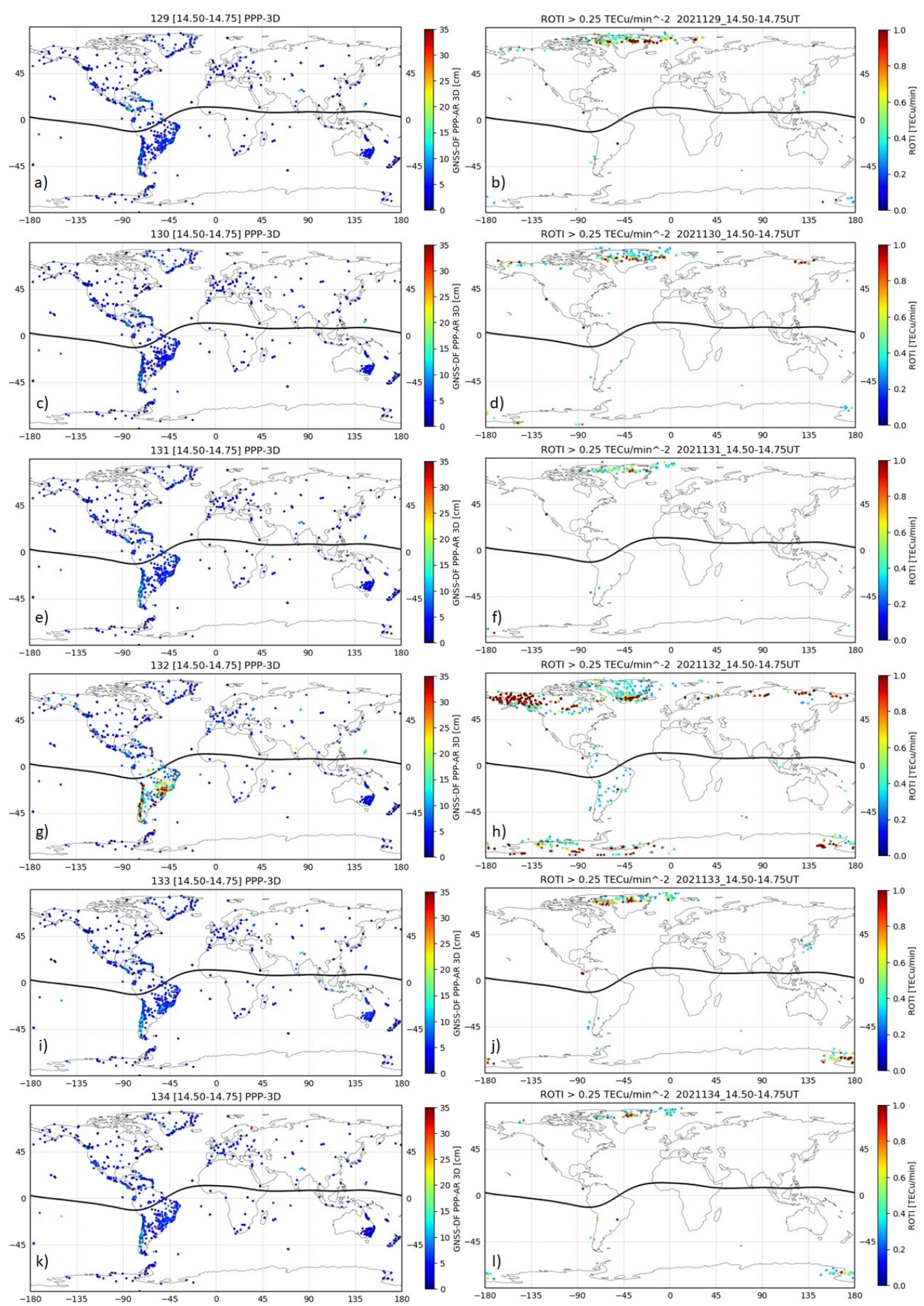

Figure 4. 3D position errors (left panels), and ROTI > $0.25 \mathrm{TECu} / \mathrm{min}$ (right panels) on (a,b) DoY 129; (c,d) DoY 130; (e,f) DoY 131; (g,h) DoY 132; (i,j) DoY 133; and (k,1) DoY 134 (between 14.50 and 14.75 UT). 

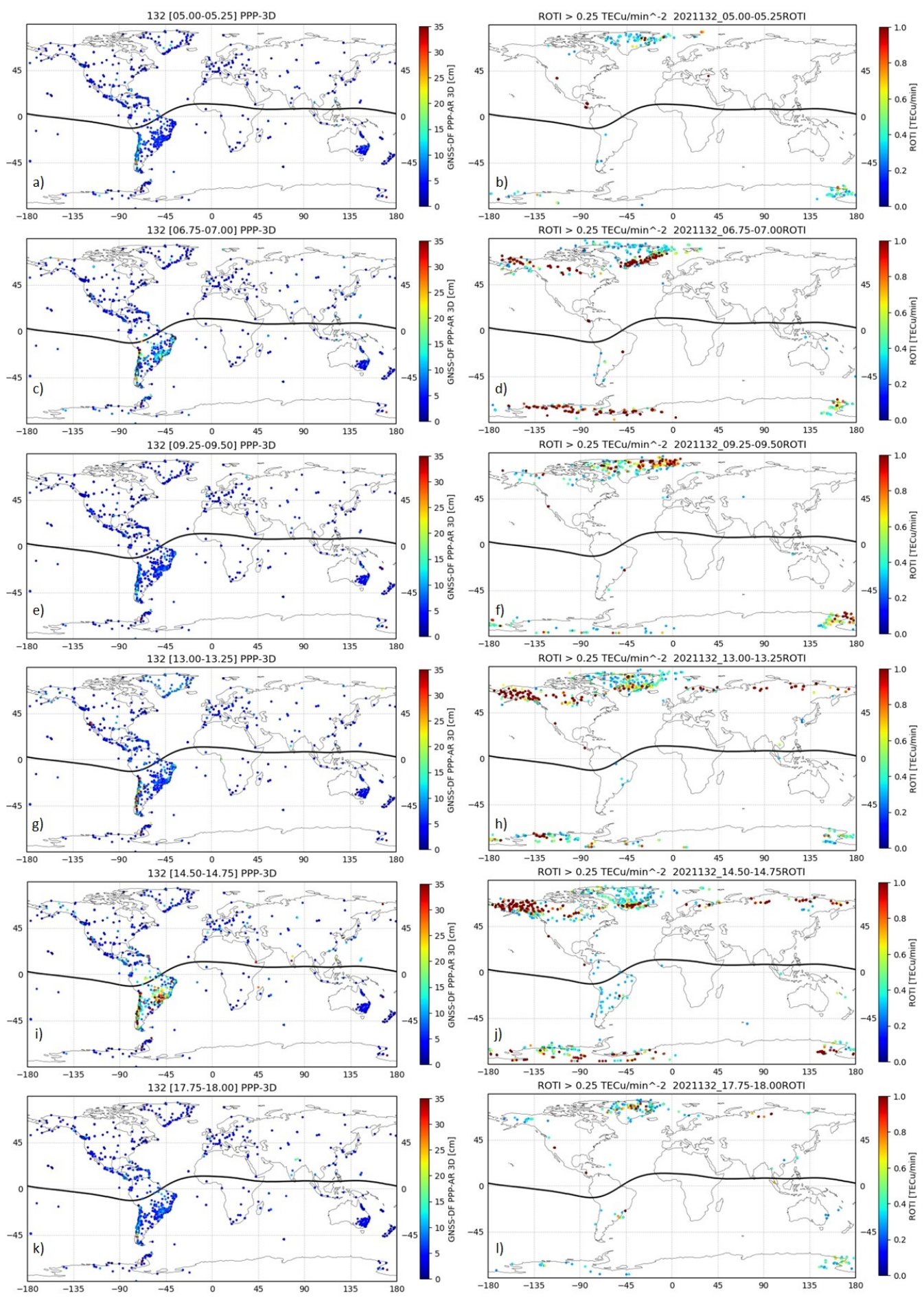

Figure 5. 3D position errors (left panels); and ROTI > $0.25 \mathrm{TECu} / \mathrm{min}$ on DoY 132 (right panels). (a,b) [5.00-5.25] UT; (c,d) [6.75-7.00] UT; (e,f) [9.25-9.50] UT; (g,h) [13.00-13.25] UT; (i,j) [14.50-14.75] UT; and (k,1) [17.75-18.00] UT. 


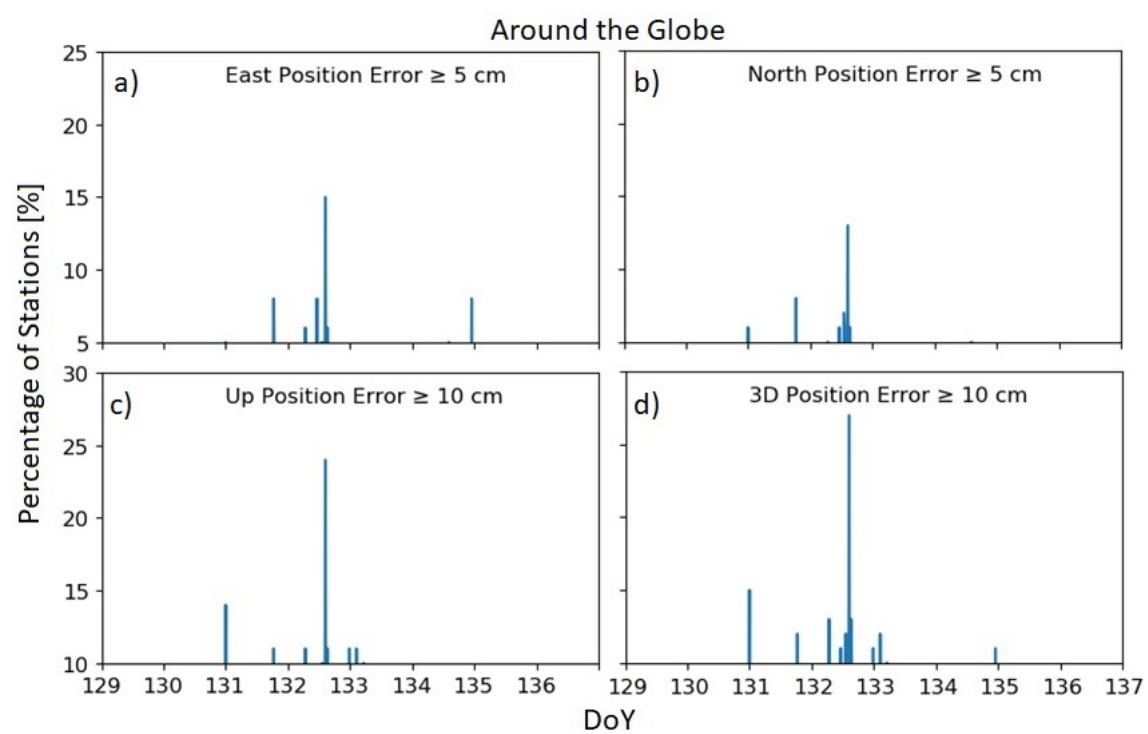

Figure 6. Time variations of percentage of stations around the globe (a) East Position Error $\geqslant 5 \mathrm{~cm}$. (b) North Position Error $\geqslant 5 \mathrm{~cm}$. (c) Up Position Error $\geqslant 10 \mathrm{~cm}$. (d) $3 D$ Position Error $\geqslant 10 \mathrm{~cm}$.

Table 2. Percentage of 868 stations around the globe with East, North, Up, and 3D position errors using the common noise filter.

\begin{tabular}{ccccccccc}
\hline $\begin{array}{c}\text { Error Intervals } \\
{[\mathbf{c m}]}\end{array}$ & $\begin{array}{c}\text { East } \\
{[\%]}\end{array}$ & $\begin{array}{c}\text { East gs } \\
{[\%]}\end{array}$ & $\begin{array}{c}\text { North } \\
{[\%]}\end{array}$ & $\begin{array}{c}\text { North gs } \\
{[\%]}\end{array}$ & $\begin{array}{c}\text { Up } \\
{[\%]}\end{array}$ & $\begin{array}{c}\text { Up gs } \\
{[\%]}\end{array}$ & $\begin{array}{c}\text { 3D } \\
{[\%]}\end{array}$ & $\begin{array}{c}\text { 3D gs } \\
{[\%]}\end{array}$ \\
\hline$<5$ & 98 & 85 & 99 & 87 & 73 & 52 & 71 & 48 \\
$5-10$ & 2 & 8 & 1 & 8 & 24 & 23 & 26 & 25 \\
$10-20$ & 0 & 5 & 0 & 2 & 3 & 16 & 3 & 17 \\
$20-40$ & 0 & 1 & 0 & 2 & 0 & 6 & 0 & 7 \\
$40-60$ & 0 & 1 & 0 & 1 & 0 & 1 & 0 & 1 \\
$60-100$ & 0 & 0 & 0 & 0 & 0 & 1 & 0 & 1 \\
$>100$ & 0 & 0 & 0 & 0 & 0 & 1 & 0 & 1 \\
\hline
\end{tabular}

Table 3. Percentage of 325 stations in South America with East, North, Up, and 3D position errors using the common noise filter.

\begin{tabular}{ccccccccc}
\hline $\begin{array}{c}\text { Error Intervals } \\
{[\mathbf{c m}]}\end{array}$ & $\begin{array}{c}\text { East } \\
{[\%]}\end{array}$ & $\begin{array}{c}\text { East gs } \\
{[\%]}\end{array}$ & $\begin{array}{c}\text { North } \\
{[\%]}\end{array}$ & $\begin{array}{c}\text { North gs } \\
{[\%]}\end{array}$ & $\begin{array}{c}\text { Up } \\
{[\%]}\end{array}$ & $\begin{array}{c}\text { Up gs } \\
{[\%]}\end{array}$ & $\begin{array}{c}\text { 3D } \\
{[\%]}\end{array}$ & $\begin{array}{c}\text { 3D gs } \\
{[\%]}\end{array}$ \\
\hline$<5$ & 98 & 70 & 98 & 72 & 55 & 13 & 50 & 9 \\
$5-10$ & 2 & 16 & 2 & 19 & 39 & 33 & 43 & 32 \\
$10-20$ & 0 & 11 & 0 & 6 & 5 & 35 & 6 & 38 \\
$20-40$ & 0 & 2 & 0 & 2 & 1 & 15 & 1 & 15 \\
$40-60$ & 0 & 1 & 0 & 1 & 0 & 1 & 0 & 2 \\
$60-100$ & 0 & 0 & 0 & 0 & 0 & 2 & 0 & 2 \\
$>100$ & 0 & 0 & 0 & 0 & 0 & 1 & 0 & 2 \\
\hline
\end{tabular}

The ROT index (ROTI) was calculated as described in Section 2.2 to study the relation of the variation of TEC in the positioning error for the 12 May 2021 geomagnetic storm. The images in the Figure 4 (right panel) show six maps of ROTI presenting the stations that had ROTI over $0.25 \mathrm{TECu} / \mathrm{min}$. Each map represents a day at the same time of the geomagnetic storm, DoYs 129, 130, 131, 133, and 134 at 14.50-14.75 UT.

We also compared the results obtained for the 12 May 2021 geomagnetic storm with the effects on the positioning error obtained for other recent moderated geomagnetic storms, 27 March 2017 and 5 August 2019. The comparison was performed by using three particular stations: one station close to Madrid (madr, $40.43^{\circ} \mathrm{N}, 4.25^{\circ} \mathrm{W}$ ) and two located in 
Chile (South America). One of the Chilean stations is located in Las Vizcachas (vzch, $33.6^{\circ} \mathrm{S}$, $\left.70.51^{\circ} \mathrm{W}\right)$ nearby to Santiago, and the second one is located in Vegas de Itata $\left(36.42^{\circ} \mathrm{S}\right.$, $\left.72.86^{\circ} \mathrm{W}\right), 400 \mathrm{~km}$ south of Santiago. The selection of the stations is based on the results of previous studies of the storms of March 2017 and August 2019 [57,61]. The August 2019 geomagnetic storm [61] was a moderate one that produced a extreme positive ionospheric storm with strong TEC perturbations over Europe. However, this work did not study positioning errors. Thus, we selected a station in Europe to be compared with the two Chilean stations, which are located in South America and in the area of interest for this work. In addition, the stations in Chile are both required since each of them was operative for different storms (see Table 4). Luo et al. [57] studied the position error produced by the moderated geomagnetic storm of March 2017 but in broad latitudinal ranges, calculating the maximum positioning errors per component for each of these ranges but not per station. Figure 7 presents the time series of TEC related indexes and the position per component for the Madrid and Vizcachas stations. The left series of images show the data for the 5 August 2019 storm. The right series of images show the data for 12 May 2021. Table 4 summarized the positioning variations at each of the three stations produced by three different geomagnetic storms.

Table 4. The root mean square (RMS), the maximum values (MAX), DVTEC, \%DVTEC, and ROTI of the Madrid ( $\left.\mathrm{madr}, 40.43^{\circ} \mathrm{N}, 4.25^{\circ} \mathrm{W}\right)$, Las Vizcachas (vzch, $\left.33.6^{\circ} \mathrm{S}, 70.51^{\circ} \mathrm{W}\right)$, Vegas de Itata $\left(36.42^{\circ} \mathrm{S}\right.$, $72.86^{\circ} \mathrm{W}$ ) stations, during the geomagnetic storms of 27 March 2017 (DoY 86), 5 August 2019 (DoY 217) and 12 May 2021 (DoY 132). DoYs 83, 84, 85 are the quiet DoYs of reference for the 27 March 2017 storm (QD-2017), DoYs 214, 215, and 216 are the quiet DoYs of reference for the August 2019 storm (QD-2019), and DoYs 129, 130, and 131 are the quiet DoYs of reference for the storm of May 2021 (QD-2021).

\begin{tabular}{|c|c|c|c|c|c|c|c|c|c|c|c|c|}
\hline \multirow{2}{*}{ Station } & \multirow{2}{*}{$\begin{array}{c}\text { DoYs } \\
\text { [Season] }\end{array}$} & \multicolumn{4}{|c|}{ RMS [cm] } & \multicolumn{4}{|c|}{$\operatorname{MAX}[\mathrm{cm}]$} & \multirow{2}{*}{$\begin{array}{l}\text { DVTEC } \\
\text { [TECu] }\end{array}$} & \multirow{2}{*}{$\begin{array}{c}\text { \%DVTEC } \\
{[\%]}\end{array}$} & \multirow{2}{*}{$\begin{array}{r}\text { ROTI } \\
{\left[\frac{T E C u}{\min }\right]} \\
\end{array}$} \\
\hline & & $\mathrm{E}$ & $\mathbf{N}$ & $\mathbf{U}$ & $3 \mathrm{D}$ & E & $\mathbf{N}$ & $\mathbf{U}$ & $3 \mathrm{D}$ & & & \\
\hline \multirow{6}{*}{ madr } & QD2017 & 0.4 & 0.5 & 1.0 & 1.1 & 1.6 & 2.0 & 5.5 & 5.7 & & & \\
\hline & $\begin{array}{l}\text { DoY } 86 \\
\text { [Spring] }\end{array}$ & 0.6 & 0.5 & 1.2 & 1.4 & 2.2 & 1.5 & 4.4 & 4.5 & 9.9 & 110 & 0.1 \\
\hline & QD2019 & 0.6 & 0.5 & 1.5 & 1.7 & 2.7 & 2.2 & 6.2 & 6.3 & & & \\
\hline & $\begin{array}{c}\text { DoY } 217 \\
\text { [Summer] }\end{array}$ & 1.0 & 0.9 & 2.8 & 2.8 & 3.1 & 2.6 & 11.6 & 11.7 & 12.0 & 153 & 0.52 \\
\hline & QD2021 & 0.7 & 0.6 & 1.7 & 1.9 & 2.4 & 2.7 & 8.7 & 8.8 & & & \\
\hline & $\begin{array}{l}\text { DoY } 132 \\
\text { [Spring] }\end{array}$ & 1.2 & 1.1 & 3.5 & 3.7 & 3.9 & 4.1 & 15.4 & 17.0 & 11.9 & 120 & 0.3 \\
\hline \multirow{5}{*}{ vzch } & $\begin{array}{c}\text { QD2017 } \\
\text { DoY } 86 \\
\text { [Fall] }\end{array}$ & & & & & & & & & & & \\
\hline & QD2019 & 0.6 & 0.5 & 1.5 & 1.7 & 5.2 & 3.7 & 15.4 & 15.4 & & & \\
\hline & $\begin{array}{l}\text { DoY } 217 \\
\text { [Winter] }\end{array}$ & 0.9 & 0.7 & 2.2 & 2.5 & 6.0 & 3.5 & 15.0 & 15.1 & 4.1 & 62 & 0.11 \\
\hline & QD2021 & 0.6 & 0.5 & 1.6 & 1.8 & 7.0 & 6.8 & 18.7 & 18.9 & & & \\
\hline & $\begin{array}{l}\text { DoY } 132 \\
\text { [Fall] }\end{array}$ & 1.5 & 1.4 & 3.8 & 4.4 & 52.4 & 52.9 & 58.8 & 82.5 & 5.3 & 56 & 0.08 \\
\hline \multirow{5}{*}{ vita } & QD2017 & 0.6 & 0.6 & 1.8 & 2.0 & 2.9 & 3.1 & 8.4 & 8.4 & & & \\
\hline & $\begin{array}{c}\text { DoY } 86 \\
\text { [Fall] }\end{array}$ & 1.0 & 1.1 & 2.8 & 3.2 & 3.5 & 3.0 & 10.0 & 10.0 & 23.5 & 150 & 0.09 \\
\hline & $\begin{array}{l}\text { QD2019 } \\
\text { DoY } 217 \\
\text { [Winter] }\end{array}$ & & & & & & & & & & & \\
\hline & QD2021 & 0.6 & 0.6 & 1.7 & 1.9 & 11.1 & 11.6 & 26.8 & 30.3 & & & \\
\hline & $\begin{array}{l}\text { DoY } 132 \\
\text { [Fall] }\end{array}$ & 1.7 & 1.2 & 4.3 & 4.8 & 52.5 & 25.0 & 41.9 & 61.2 & 5.1 & 51 & 0.13 \\
\hline
\end{tabular}



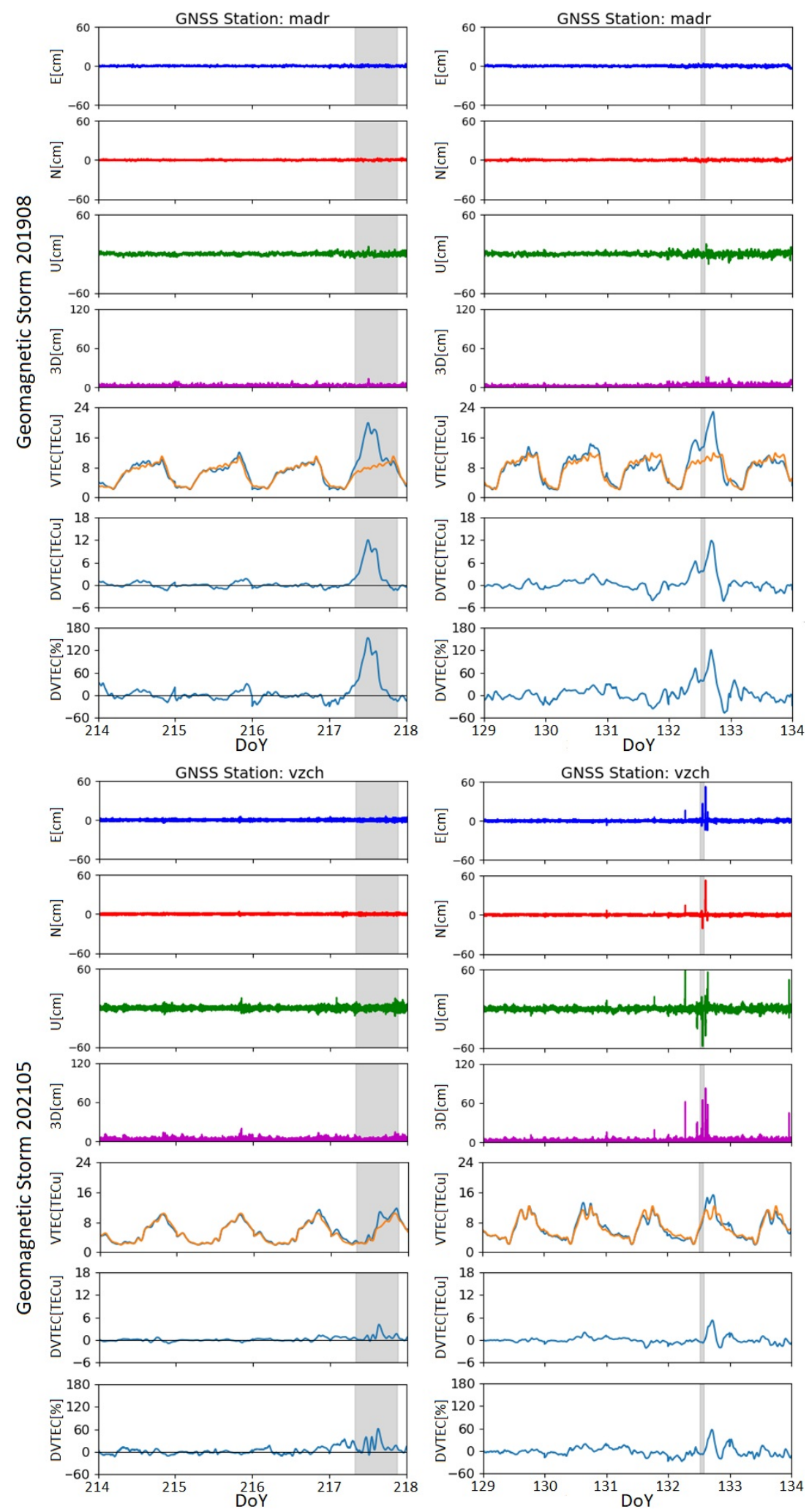

Figure 7. The positioning errors of each component and the different TEC variations-related indexes (VTEC, DVTEC, and \%DVTEC). The (left panels) show the effects of the 5 August 2019 storm. The (right panels) show the effects of the 12 May 2021 storm. The (top panels) and (bottom panels) present the Madrid (madr, $40.43^{\circ} \mathrm{N}, 4.25^{\circ} \mathrm{W}$ ) and Las Vizcachas (vzch, 33.6 ${ }^{\circ} \mathrm{S}, 70.51^{\circ} \mathrm{W}$ ) stations, respectively. On displays representing VTEC, the orange line represents VTEC mean calculated with the reference days. We plotted the VTEC mean in all the studied days to compare it with the VTEC of each of the days (blue line). 


\section{Discussion and Main Conclusions}

In this section, we discuss the main findings regarding the geomagnetic storm of 12 May 2021.The main goal is to study the positioning errors of GNSS receivers caused by this storm, which can be classified as a moderate one. In addition, in order to verify our methodology and our findings we used previous equivalent geomagnetic storms as comparison. The comparison storms were the 27 March 2017 [61] and the 5 August 2019 [57].

\subsection{May 2021 Geomagnetic Storm}

The geomagnetic storm under study occurred in 12 May 2021. It can be classified as moderated in terms of Dst and strong in terms of Kp (Dst $=-61 \mathrm{nT}, \mathrm{Kp}=7$, and $\mathrm{AE}=\sim 1500 \mathrm{nT}$ ). This storm is the first strong storm, in terms of Kp, of the solar cycle 25. The main phase of this storm lasted one hour from 13 UT to 14 UT, with the Dst peak at 14 UT (see Figure 2). Since the storm occurred in May the southern and northern hemispheres were in fall and spring seasons, respectively. During the main phase of the storm the Sun moved from the $\left(18.27^{\circ} \mathrm{N}, 15.91^{\circ} \mathrm{W}\right)$ to the $\left(18.28^{\circ} \mathrm{N}, 30.91^{\circ} \mathrm{W}\right)$ coordinates. This storm caused important effects on the GNSS stations in South America (see Figures 3 and $4 \mathrm{~g}$ plot), which are rare for this type of storm.

\subsection{The 27 March 2017 and 5 August 2019 Geomagnetic Storms}

In Table 1, we present previous works where the positioning errors were studied. In this table, we can see two moderate geomagnetic storms in terms of the Dst and $\mathrm{Kp}$ classifications, the 7 January 2015 (Dst $=-99 \mathrm{nT}, \mathrm{Kp}=6$ ) and 27 March (Dst $=-74 \mathrm{nT}$, $\mathrm{Kp}=6$ ). The 2015 geomagnetic storm, unlike the 12 May 2021 storm, took place during the solar maximum period of the solar cycle 24 . In addition, the January 2015 storm occurred during the summer season in the southern hemisphere. The 27 March storm occurred during the descent period of the solar cycle 24 . Then, it had similar solar activity compared to the May 2021 storm. Moreover, the March 2017 storm, like the May 2021 storm, was on the fall season in the southern hemisphere, with the Sun moving from the $\left(2.69^{\circ} \mathrm{N}, 91.35^{\circ} \mathrm{W}\right)$ to the $\left(2.83^{\circ} \mathrm{N}, 43.68^{\circ} \mathrm{W}\right)$ coordinates. For these reasons. we discarded the 7 January 2015 storm as a good comparison storm and selected 27 March 2017 as a good one. The main phase of the March 2017 geomagnetic storm was much longer than that of the May 2021 storm (6-15 UT).

On the other hand, a recent study presented the case of a moderated geomagnetic storm occurring on 5 August 2019 (Dst peak $=-53 \mathrm{nT}, \mathrm{Kp}=5^{+}, \mathrm{AE} \sim 1000 \mathrm{nT}$ ) which produced a strong positive (decrease in electrons) ionospheric storm [61]. Although this geomagnetic storm was less intense than the May 2021 storm, its main phase was much longer (8-21 UT). During this storm, the southern hemisphere was in winter, then, like in May 2021, the Sun was over the northern hemisphere (from $\left(17.01^{\circ} \mathrm{N}, 61.52^{\circ} \mathrm{E}\right.$ ) to $\left.\left(16.86^{\circ} \mathrm{N}, 133.50^{\circ} \mathrm{W}\right)\right)$. Thus, we used this storm as a comparison to the May $2021 \mathrm{storm}$. Unfortunately, the study of this storm did not analyze the positioning error caused by it. The study showed that the European sector was one of the most affected in terms of TEC variations. For this reason, the comparison was performed including a GNSS located in Europe (close to Madrid, Spain). The other two stations located in Chile were used, since that region was one of the most perturbed areas in terms of position during the May 2021 storm (see Figure $4 \mathrm{~g}$ plot).

\subsection{Ionospheric Effects}

From Figure 3, we can see that the VTEC is perturbed around the globe, including the southern part of America during the main phase of the May 2021 geomagnetic storm. On the other hand, in Figure $4 \mathrm{~h}$, we can see an increment in ROTI, that starts at the polar regions, propagating later the increment toward the equator, agreeing with previous studies $[77,78]$ (see Figure 5). In Figure 7 , it is possible to see the VTEC and DVTEC perturbations of the GNSS stations over Madrid, Spain and Santiago, Chile (Vizcacha station) for the May 2021 storm. In comparison, we also present the VTEC and DVTEC 
perturbations on the same stations produced by the August 2019 storm. It is noticeable that TEC variations are similar between storms for the same station. In addition, the difference in the variations between the stations in southern and northern hemispheres is evident. The TEC variation seems stronger in the northern station. In Table 4, we can see that the VTEC is in percentage much higher over Madrid (Spain) than over Santiago (Chile) and Vega de Itata (Chile) for most of the storms, except for the March 2017 storm. We also calculated the ROT index for the May 2021 storm period. Five stations localized in high latitudes had values of maximum ROTI peak between 3.4 and $3.9 \mathrm{TECu} / \mathrm{min}$, and average ROTI peak $\sim 1.1 \mathrm{TECu} / \mathrm{min}$, and these values are similar to those presented by Kotulak et al. [77] for moderate geomagnetic storms.

\subsection{Positioning Errors}

The manner in which we quantified the positioning errors in this work was through the statistics of perturbed stations around the world and in particular in the South American sector. Our RMS position values for the quiet days are in accordance with the results presented by Katsigianni et al. [79]. They gathered that the performances of the kinematic postprocessed PPP-AR method are $\leqslant 0.8$ and $\leqslant 2 \mathrm{~cm}$ for the horizontal components and the vertical component, respectively. Table 2 shows that for the quiet days, $71 \%$ of the stations had an error less than $5 \mathrm{~cm}$ in the 3D estimation. Table 2 also shows that for the May 2021 geomagnetic storm the main increment suffered by the Up component, passing from $27 \%$ of the total stations (868) with perturbations over $5 \mathrm{~cm}$ to $48 \%$. Although the impact over the North and East components was less affected, they jumped from $1 \%$ to $13 \%$ and from $2 \%$ to $15 \%$, respectively, for the stations with errors over $5 \mathrm{~cm}$. Figure 6 graphically shows this increment in the number of stations over certain level of positioning error for a period of time that include the main phase of the May 2021 storm, also showing that the Up component is the most affected. The TEC (Figure 3) and ROTI (Figure 5h) plots show that for the May 2021 storm the main geophysical activity concentrated on the poles and on the South America sector. However, Figure $5 \mathrm{~g}$ shows that the positioning errors were perceived mainly in stations in the South American sector. Table 3 shows that in the Up component, we went from $45 \%$ of the total station over South America (325) with an error over $5 \mathrm{~cm}$ to $87 \%$. The similar increment can be perceived for the other components. In the North component, we passed from $2 \%$ to $28 \%$ of stations over an error of $5 \mathrm{~cm}$. Similarly in the East component, the variation went from $2 \%$ to $30 \%$ for the same error range. Only $1 \%$ of the stations had errors over $40 \mathrm{~cm}$ in the North and East components during the May 2021 storm, while for the Up component with errors over $40 \mathrm{~cm}$, the stations percentage reached $4 \%$. Furthermore, the persistence of the position errors caused by the 12 May 2021 geomagnetic storm lasted for $9.25 \mathrm{~h}$ [6.50-15.75 UT] (Figures 2d-f, 6 and 7 right panels).

We compared the effects obtained over the positioning error due to the May 2021 storm, with the effects of the moderate geomagnetic storms that occurred on 27 March 2017 and 5 August 2019. Figure 7 compares the effects on the position in two different GNSS stations, one in Chile (South America sector) and one in Europe, where a previous storm produced strong ionospheric effects during the 5 August 2019 geomagnetic storm [16]. From the comparison, it is possible to notice that the perturbations in the position are much higher in the Vizcacha (Santiago, Chile) station and for the May 2021 storm. This is an intriguing result. Both storms, May 2021 and August 2019, are very similar, except for the duration of the main phases, but still, they produced very different effects on the position estimation (see Figure 7). Even more puzzling is the fact that the August 2019 storm has been reported to produce a strong ionospheric storm that affected the European sector [61]. For instance, the \%DVTEC is almost double that in the Madrid station compared to the Santiago station (Vizcachas station), but we have found with our analysis on one station in the European sector that it did not impact the position estimation.

Table 4 presents the positioning error and \%DVTEC data for the three selected for comparison stations (one in Europe and two in South America) during three moderate geomagnetic storms. It is possible to notice the same pattern as that obtained between the 
May 2021 and August 2019 storms which was obtained between the March 2017 and the May 2021 storms. Thus, the effects over the position estimation were very severe during the May 2021 storm over the South America sector (Vega de Itata, vita-station), even though the \%DVTEC was much higher for the March 2017 storm both for Spain (Madrid) and Chile (vita) stations.

The ROTI also has an intriguing behavior. We observe an increase in the number of stations with ROTI > 0.25 TECu/min (Figure 5) especially in the poles and the South American region. In North America and northern Europe region, the number of stations with activity increased from 50\% to $94 \%$. In the Antarctic region, there was an increase from $12 \%$ to $62 \%$ of stations with activity. In South America, the percentage passed from $1.5 \%$ to $10.5 \%$ of the stations with activity. Nevertheless, we do not find a significant increase in the number of stations with higher positioning errors over the poles. Therefore, it is conclusive that the fast variations of TEC might be responsible for the variations over the South American sector.

Our results did not confirm that positioning errors increased rapidly with increasing ROTI (Figures 2d-f,j, 4g,h, 5 and 7; Table 4) as several studies suggest [56-58,60]. Therefore, our results suggested that position errors also occur, regardless of whether the ROTI has rapid variations, if it is $\mathrm{ROTI}<0.25 \mathrm{TECu} / \mathrm{min}$ or no ROTI variations are appreciated.

In summary, the analyzed data show that the moderate 12 May 2021 geomagnetic storm strongly affected the GNSS precision for about an hour in several GNSS receivers, mainly on stations located in the South American sector. Comparison with previous moderate storms (27 March 2017 and 5 August 2019) showed that the effects in the position estimation are not directly deducible from the geomagnetic storms characteristics. The three analyzed storms were moderated, although the 12 May 2021 storm had a higher Kp, which tends to be a good indicator of midlatitude activity. By using three stations we compare the effects of the three storms, showing that the effects are stronger on the South American sector even though the ionospheric effects (DVTEC) are not severe.

The positioning error data show that the horizontal coordinates are more robust to TEC perturbations, although the error in the vertical component is still high. In the literature, the vertical coordinate tends to be neglected, but for current and future GNSS applications, it might be relevant. It could be important for autonomous aerial applications or for high-precision activities. The mining, agriculture, fishing, and disaster-control sectors in Chile are starting to adopt autonomous or tele-operated systems that might be sensitive to ionopsheric perturbations. The relevant height of the vehicles in these industries might impose a serious risk for infrastructure or people if the vertical error in the GNSS receiver skyrockets. For instance, for open-pit mines, a high vertical error may cause a failure in the estimation of the terrace in which a vehicle is with the consequent risk of falling. Potential risks could be reduced by stopping autonomous operations during these events. However, our results show that it is hard to predict when a storm will have serious effects over the position accuracy. False positives in the forecasting can be complex for these industries, since stopping operation even for a short time, such as an hour, could be prohibitively expensive. The new solar cycle is critical to unravel the relation between solar activity and positioning errors in the GNSS receivers thanks to the large number of GNSS stations available around the world, gathering relevant data. However, we need to process the data in a standardized manner that facilitates comparison between different cycles, paying attention to the storms that produce unexpected behaviors such as those in the 12 May 2021 geomagnetic storm.

Author Contributions: Conceptualization, J.C.V.-A. and M.A.D.; data curation, J.C.V.-A., M.A.D., J.C.B., and Y.S.-S.; formal analysis, J.C.V.-A. and M.A.D.; funding acquisition, M.A.D.; investigation, J.C.V.-A., M.A.D., J.C.B., and Y.S.-S.; methodology, J.C.V.-A.; project administration, M.A.D.; resources, M.A.D. and J.C.B.; software, J.C.V.-A. and Y.S.-S.; supervision, M.A.D.; validation, J.C.V.-A., M.A.D., J.C.B., and Y.S.-S.; visualization, J.C.V.-A. and Y.S.-S.; writing-original draft, M.A.D. and Y.S.-S.; writing-review and editing, J.C.B. All authors have read and agreed to the published version of the manuscript. 
Funding: This research was funded by the Air Force Office of Scientific Research under award numbers FA9550-18-1-0249, FA9550-20-1-0189, and FA9550-19-1-0384. This work was also partially funded by the ANID-FONDECYT grants 1211144 and 1221907, the ANID AFB180004 project (Advanced Mining Technology Center), and CONICYT Doctoral Grant Number 21181599. J.C.B. was also supported by ANID PIA (ACT192169) and supported by Fondecyt projects ( $\mathrm{N}^{\circ} 1200779$ and No1181479, ANID, Chile).

Institutional Review Board Statement: Not applicable.

Informed Consent Statement: Not applicable.

Data Availability Statement: The RINEX files were obtained from: International GNSS services (IGS) stations; the Chilean network of GNSS receivers set up by the National Seismological Center at University of Chile (CSN in Spanish); the Argentine Continuous Satellite Monitoring Network (RAMSAC in Spanish); the Brazilian Network for Continuous Monitoring of the Institute of Brazilian Geography and Statistics (IGBE in Portuguese); and the Crustal Dynamics Data Information System (CDDIS) of the National Aeronautics and Space Administration (NASA); University NAVSTAR Consortium (UNAVCO); the Geoscience Australia; and the African Geodetic Reference Frame (AFREF).

Conflicts of Interest: The authors declare no conflict of interest.

\section{References}

1. Adebiyi, S.; Ikubanni, S.; Adebesin, B.; Joshua, B.; Adekoya, B. Variations of GPS-TEC at an African Low Latitude Station during Geomagnetic Disturbances. Phys. Mem.-J. Theor. Appl. Phys. 2019, 1, 113-125.

2. Gonzalez, W.D.; Tsurutani, B.T.; De Gonzalez, A.L.C. Interplanetary origin of geomagnetic storms. Space Sci. Rev. 1999, 88, 529-562. [CrossRef]

3. Tsidu, G.M.; Abraha, G. Moderate geomagnetic storms of 22-25 January 2012 and their influences on the wave components in ionosphere and upper stratosphere-mesosphere regions. Adv. Space Res. 2014, 54, 1793-1812. [CrossRef]

4. Gonzalez, W.; Joselyn, J.A.; Kamide, Y.; Kroehl, H.W.; Rostoker, G.; Tsurutani, B.; Vasyliunas, V. What is a geomagnetic storm? J. Geophys. Res. Space Phys. 1994, 99, 5771-5792. [CrossRef]

5. Joshua, B.; Adeniyi, J.; Adimula, I.; Oladipo, O.; Olawepo, O.; Adebiyi, S. Ionospheric response to the storm-time disturbance of 29 May, 2010. Adv. Space Res. 2014, 53, 219-225. [CrossRef]

6. Joshua, B.; Adeniyi, J.; Reinisch, B.; Adimula, I.; Olawepo, A.; Oladipo, O.; Adebiyi, S. The response of the ionosphere over Ilorin to some geomagnetic storms. Adv. Space Res. 2014, 54, 2224-2235. [CrossRef]

7. Davis, T.N.; Sugiura, M. Auroral electrojet activity index AE and its universal time variations. J. Geophys. Res. 1966, 71, 785-801. [CrossRef]

8. Boroyev, R.; Vasiliev, M. Relationship of the ASY-H index with interplanetary medium parameters and auroral activity in magnetic storm main phases during CIR and ICME events. Sol.-Terr. Phys. 2020, 6, 35-40. [CrossRef]

9. Adebesin, B.; Ikubanni, S.; Kayode, J.; Adekoya, B. Variability of solar wind dynamic pressure with solar wind parameters during intense and severe storms. Afr. Rev. Phys. 2013, 8, 119-128.

10. Borovsky, J.E.; Shprits, Y.Y. Is the Dst index sufficient to define all geospace storms? J. Geophys. Res. Space Phys. 2017, 122, 11-543. [CrossRef]

11. Matzka, J.; Stolle, C.; Yamazaki, Y.; Bronkalla, O.; Morschhauser, A. The Geomagnetic Kp Index and Derived Indices of Geomagnetic Activity. Space Weather 2021, 19, e2020SW002641. [CrossRef]

12. Ferreira, A.A.; Borges, R.A. Performance Analysis of Distinct Feed-forward Neural Networks Structures on the AE Index Prediction. In Proceedings of the 2021 IEEE Aerospace Conference (50100), Big Sky, MT, USA, 6-13 June 2021; pp. 1-7.

13. Desai, M.V.; Shah, S.N. Impacts of intense geomagnetic storms on NavIC/IRNSS system. Ann. Geophys. 2018, 61, 557. [CrossRef]

14. Gonzalez, W.; Echer, E. A study on the peak Dst and peak negative Bz relationship during intense geomagnetic storms. Geophys. Res. Lett. 2005, 32. [CrossRef]

15. Mendillo, M. Storms in the ionosphere: Patterns and processes for total electron content. Rev. Geophys. 2006, 44. [CrossRef]

16. Joshua, B.; Adeniyi, J.; Oladipo, O.; Doherty, P.; Adimula, I.; Olawepo, A.; Adebiyi, S. Simultaneous response of NmF2 and GPS-TEC to storm events at Ilorin. Adv. Space Res. 2018, 61, 2904-2913. [CrossRef]

17. Cai, X.; Burns, A.G.; Wang, W.; Qian, L.; Solomon, S.C.; Eastes, R.W.; McClintock, W.E.; Laskar, F. Investigation of a neutral "tongue" observed by GOLD during the geomagnetic storm on May 11, 2019. J. Geophys. Res. Space Phys. 2021, 126, e2020JA028817. [CrossRef]

18. Yu, T.; Wang, W.; Ren, Z.; Yue, J.; Yue, X.; He, M. Middle-Low Latitude Neutral Composition and Temperature Responses to the 20 and 21 November 2003 Superstorm From GUVI Dayside Limb Measurements. J. Geophys. Res. Space Phys. 2021, 126, e2020JA028427. [CrossRef]

19. Verkhoglyadova, O.P.; Tsurutani, B.T.; Mannucci, A.J.; Saito, A.; Araki, T.; Anderson, D.; Abdu, M.; Sobral, J. Simulation of PPEF effects in dayside low-latitude ionosphere for the 30 October 2003, superstorm. Wash. DC Am. Geophys. Union Geophys. Monogr. Ser. 2008, 181, 169-177. 
20. Inyurt, S. Investigation of Ionospheric Variations During Magnetic Storm Over Turkey. Geomagn. Aeron. 2020, 60, 131-135. [CrossRef]

21. Liu, L.; Wan, W.; Zhang, M.L.; Zhao, B.; Ning, B. Prestorm enhancements in NmF2 and total electron content at low latitudes. J. Geophys. Res. Space Phys. 2008, 113. [CrossRef]

22. Gao, Q.; Liu, L.B.; Zhao, B.Q.; Wan, W.X.; Zhang, M.L.; Ning, B.Q. Statistical Study of the Storm Effects in Middle and Low Latitude Ionosphere in the East-Asian Sector. Chin. J. Geophys. 2008, 51, 435-443. [CrossRef]

23. Stankov, S.; Stegen, K.; Warnant, R. Seasonal variations of storm-time TEC at European middle latitudes. Adv. Space Res. 2010, 46, 1318-1325. [CrossRef]

24. Sharma, S.; Galav, P.; Dashora, N.; Dabas, R.; Pandey, R. Study of ionospheric TEC during space weather event of 24 August 2005 at two different longitudes. J. Atmos. Sol.-Terr. Phys. 2012, 75, 133-140. [CrossRef]

25. Blagoveshchenskii, D. Effect of geomagnetic storms (substorms) on the ionosphere: 1. A review. Geomagn. Aeron. 2013, 53, 275-290. [CrossRef]

26. Cherniak, I.; Zakharenkova, I.; Redmon, R.J. Dynamics of the high-latitude ionospheric irregularities during the 17 March $2015 S t$. Patrick's Day storm: Ground-based GPS measurements. Space Weather 2015, 13, 585-597. [CrossRef]

27. Fagundes, P.R.; Cardoso, F.; Fejer, B.; Venkatesh, K.; Ribeiro, B.; Pillat, V. Positive and negative GPS-TEC ionospheric storm effects during the extreme space weather event of March 2015 over the Brazilian sector. J. Geophys. Res. Space Phys. 2016, 121, 5613-5625. [CrossRef]

28. Tsurutani, B.; Mannucci, A.; Iijima, B.; Abdu, M.A.; Sobral, J.H.A.; Gonzalez, W.; Guarnieri, F.; Tsuda, T.; Saito, A.; Yumoto, K.; et al. Global dayside ionospheric uplift and enhancement associated with interplanetary electric fields. J. Geophys. Res. Space Phys. 2004, 109. [CrossRef]

29. Mannucci, A.; Tsurutani, B.; Iijima, B.; Komjathy, A.; Saito, A.; Gonzalez, W.; Guarnieri, F.; Kozyra, J.; Skoug, R. Dayside global ionospheric response to the major interplanetary events of 29-30 October 2003 "Halloween Storms". Geophys. Res. Lett. 2005, 32. [CrossRef]

30. Lastovicka, J. Monitoring and forecasting of ionospheric space weather-effects of geomagnetic storms. J. Atmos. Sol.-Terr. Phys. 2002, 64, 697-705. [CrossRef]

31. Fuller-Rowell, T.; Codrescu, M.; Rishbeth, H.; Moffett, R.; Quegan, S. On the seasonal response of the thermosphere and ionosphere to geomagnetic storms. J. Geophys. Res. 1996, 101, 2343-2353. [CrossRef]

32. Kleimenova, N.; Gromova, L.; Gromov, S.; Malysheva, L. Strong Magnetic Storm on 25-26 August 2018 with Reference to the Solar Cycle 24 Declining. Sol. Influ. Magnetos. Ionos. Atmos. 2019, 107-112. [CrossRef]

33. Kleimenova, N.; Gromova, L.; Gromov, S.; Malysheva, L. The Magnetic Storm of August 25-26. 2018: Dayside High Latitude Geomagnetic Variations and Pulsations. Geomagn. Aeron. 2019, 59, 660-667. [CrossRef]

34. Redmon, R.; Seaton, D.; Steenburgh, R.; He, J.; Rodriguez, J. September 2017's geoeffective space weather and impacts to Caribbean radio communications during hurricane response. Space Weather 2018, 16, 1190-1201. [CrossRef]

35. Aa, E.; Huang, W.; Liu, S.; Ridley, A.; Zou, S.; Shi, L.; Chen, Y.; Shen, H.; Yuan, T.; Li, J.; et al. Midlatitude plasma bubbles over China and adjacent areas during a magnetic storm on 8 September 2017. Space Weather 2018, 16, 321-331. [CrossRef]

36. SAĞIR, S.; ATICI, R.; DÖLEK, İ. Investigation of the Severe Geomagnetic Storm Effects on Ionosphere at Nighttime through ROTI. Muş Alparslan Üniv. Fen Bilim. Derg. 2018, 6, 603-609.

37. Teh, W.L.; Chen, W.S. Dependency of the Ionospheric Storm on the Local Time of Storm Onset in the Southeast Asia Sector. In Proceedings of the 2019 6th International Conference on Space Science and Communication (IconSpace), Johor Bahru, Malaysia, 28-30 July 2019; pp. 9-13. [CrossRef]

38. Zhang, Y.; Liu, Y.; Mei, J.; Zhang, C.; Wang, J. A Study on the Characteristics of the Ionospheric Gradient under Geomagnetic Perturbations. Sensors 2020, 20, 1805. [CrossRef] [PubMed]

39. Wen, D.; Mei, D. Ionospheric TEC disturbances over China during the strong geomagnetic storm in September 2017. Adv. Space Res. 2020, 65, 2529-2539. [CrossRef]

40. Fedrizzi, M.; de Paula, E.R.; Kantor, I.J.; Langley, R.B.; Santos, M.C.; Komjathy, A. Mapping the low-latitude ionosphere with GPS. GPS World 2002, 13, 41-47.

41. Batista, I.S.; Abdu, M.; Souza, J.; Bertoni, F.; Matsuoka, M.; Camargo, P.; Bailey, G. Unusual early morning development of the equatorial anomaly in the Brazilian sector during the Halloween magnetic storm. J. Geophys. Res. Space Phys. 2006, 111. [CrossRef]

42. de Abreu, A.; Sahai, Y.; Fagundes, P.R.; Becker-Guedes, F.; de Jesus, R.; Guarnieri, F.; Pillat, V.G. Response of the ionospheric F-region in the Brazilian sector during the super geomagnetic storm in April 2000 observed by GPS. Adv. Space Res. 2010, 45, 1322-1329. [CrossRef]

43. Nogueira, P.; Abdu, M.; Batista, I.; De Siqueira, P. Equatorial ionization anomaly and thermospheric meridional winds during two major storms over Brazilian low latitudes. J. Atmos. Sol.-Terr. Phys. 2011, 73, 1535-1543. [CrossRef]

44. De Siqueira, P.; De Paula, E.; Muella, M.; Rezende, L.; Abdu, M.; Gonzalez, W. Storm-time total electron content and its response to penetration electric fields over South America. Ann. Geophys. 2011, 29, 1765-1778. [CrossRef]

45. De Abreu, A.; Sahai, Y.; Fagundes, P.; De Jesus, R.; Bittencourt, J.; Pillat, V. An investigation of ionospheric F region response in the Brazilian sector to the super geomagnetic storm of May 2005. Adv. Space Res. 2011, 48, 1211-1220. [CrossRef] 
46. Figueiredo, C.; Wrasse, C.; Takahashi, H.; Otsuka, Y.; Shiokawa, K.; Barros, D. Large-scale traveling ionospheric disturbances observed by GPS dTEC maps over North and South America on Saint Patrick's Day storm in 2015. J. Geophys. Res. Space Phys. 2017, 122, 4755-4763. [CrossRef]

47. Bravo, M.; Villalobos, C.; Leiva, R.; Tamblay, L.; Vega-Jorquera, P.; Ovalle, E.; Foppiano, A. Ionospheric Response to the Space Weather Events of 4-10 September 2017: First Chilean Observations. Open Atmos. Sci. J. 2019, 13. [CrossRef]

48. Macho, E.P.; Correia, E.; Paulo, C.M.; Angulo, L.; Vieira, J.A.G. Ionospheric response to the June 2015 geomagnetic storm in the South American region. Adv. Space Res. 2020, 65, 2172-2183. [CrossRef]

49. Kuai, J.; Liu, L.; Lei, J.; Liu, J.; Zhao, B.; Chen, Y.; Le, H.; Wang, Y.; Hu, L. Regional differences of the ionospheric response to the July 2012 geomagnetic storm. J. Geophys. Res. Space Phys. 2017, 122, 4654-4668. [CrossRef]

50. Gao, Y., Precise Point Positioning (PPP). In Encyclopedia of Geodesy; Springer International Publishing: Cham, Switzerland, 2016; pp. 1-5. [CrossRef]

51. Jacobsen, K.S.; Andalsvik, Y.L. Overview of the 2015 St. Patrick's day storm and its consequences for RTK and PPP positioning in Norway. J. Space Weather Space Clim. 2016, 6, A9. [CrossRef]

52. Yang, L.; Gao, J.; Li, Z.; Li, F.; Chen, C.; Wang, Y. New Satellite Selection Approach for GPS/BDS/GLONASS Kinematic Precise Point Positioning. Appl. Sci. 2019, 9, 5280. [CrossRef]

53. Abdallah, A.; Saifeldin, A.; Abomariam, A.; Ali, R. Efficiency of using GNSS-PPP for digital elevation model (DEM) production. Artif. Satell. 2020, 55, 17-28. [CrossRef]

54. Yigit, C.O. Experimental assessment of post-processed kinematic Precise Point Positioning method for structural health monitoring. Geomat. Nat. Hazards Risk 2016, 7, 360-383. [CrossRef]

55. Mendez Astudillo, J.; Lau, L.; Tang, Y.T.; Moore, T. Analysing the Zenith Tropospheric Delay Estimates in On-line Precise Point Positioning (PPP) Services and PPP Software Packages. Sensors 2018, 18, 580. [CrossRef]

56. Shagimuratov, I.; Chernouss, S.; Despirak, I.; Filatov, M.; Efishov, I.; Tepenitsyna, N.Y. Occurrence of TEC fluctuations and GPS positioning errors at different longitudes during auroral disturbances. Sun Geosph. 2018, 13, 89-94. [CrossRef]

57. Luo, X.; Gu, S.; Lou, Y.; Xiong, C.; Chen, B.; Jin, X. Assessing the performance of GPS precise point positioning under different geomagnetic storm conditions during solar cycle 24. Sensors 2018, 18, 1784. [CrossRef]

58. Poniatowski, M.; Nykiel, G. Degradation of Kinematic PPP of GNSS Stations in Central Europe Caused by Medium-Scale Traveling Ionospheric Disturbances During the St. Patrick's Day 2015 Geomagnetic Storm. Remote Sens. 2020, 12, 3582. [CrossRef]

59. Yasyukevich, Y.; Vasilyev, R.; Ratovsky, K.; Setov, A.; Globa, M.; Syrovatskii, S.; Yasyukevich, A.; Kiselev, A.; Vesnin, A. Small-Scale Ionospheric Irregularities of Auroral Origin at Mid-Latitudes during the 22 June 2015 Magnetic Storm and Their Effect on GPS Positioning. Remote Sens. 2020, 12, 1579. [CrossRef]

60. Yang, Z.; Mrak, S.; Morton, Y.J. Geomagnetic Storm Induced Mid-latitude Ionospheric Plasma Irregularities and Their Implications for GPS Positioning over North America: A Case Study. In Proceedings of the 2020 IEEE/ION Position, Location and Navigation Symposium (PLANS). IEEE, Portland, OR, USA, 20-23 April 2020; pp. 234-238. [CrossRef]

61. Rajesh, P.; Lin, C.; Lin, C.; Chen, C.H.; Liu, J.; Matsuo, T.; Chen, S.P.; Yeh, W.; Huang, C. Extreme Positive Ionosphere Storm Triggered by a Minor Magnetic Storm in Deep Solar Minimum Revealed by FORMOSAT-7/COSMIC-2 and GNSS Observations. J. Geophys. Res. Space Phys. 2021, 126, e2020JA028261. [CrossRef]

62. Seemala, G.; Valladares, C. Statistics of total electron content depletions observed over the South American continent for the year 2008. Radio Sci. 2011, 46. [CrossRef]

63. Piñón, D.A.; Gómez, D.D.; Smalley, R.; Cimbaro, S.R.; Lauría, E.A.; Bevis, M.G. The history, state, and future of the Argentine continuous satellite monitoring network and its contributions to geodesy in Latin America. Seismol. Res. Lett. 2018, 89, 475-482. [CrossRef]

64. Orus, R.; Hernandez-Pajares, M.; Juan, J.; Sanz, J. Improvement of global ionospheric VTEC maps by using kriging interpolation technique. J. Atmos. Sol.-Terr. Phys. 2005, 67, 1598-1609. [CrossRef]

65. Monte Moreno, E.; García Rigo, A.; Hernández-Pajares, M.; Yang, H. TEC Forecasting Based on Manifold Trajectories. Remote Sens. 2018, 10, 988. [CrossRef]

66. Monte-Moreno, E.; Hernandez-Pajares, M.; Lyu, H.; Yang, H.; Aragon-Angel, A. Estimation of Polar Depletion Regions by VTEC Contrast and Watershed Enhancing. IEEE Trans. Geosci. Remote. Sens. 2021, 1-20. [CrossRef]

67. Yang, H.; Monte-Moreno, E.; Hernandez-Pajares, M.; Roma-Dollase, D. Real-time interpolation of global ionospheric maps by means of sparse representation. J. Geod. 2021, 95, 1-20. [CrossRef]

68. Basu, S.; Groves, K.; Quinn, J.; Doherty, P. A comparison of TEC fluctuations and scintillations at Ascension Island. J. Atmos. Sol.-Terr. Phys. 1999, 61, 1219-1226. [CrossRef]

69. Ma, G.; Maruyama, T. A super bubble detected by dense GPS network at east Asian longitudes. Geophys. Res. Lett. 2006, 33. [CrossRef]

70. Ke, F.; Qi, X.; Wang, Y.; Liu, X. Statistics of ionospheric responses to Southeast Asia's typhoons during 2006-2018 using the rate of change in the TEC index. Adv. Space Res. 2020, 66, 1724-1742. [CrossRef]

71. Harsha, P.B.S.; Ratnam, D.V.; Nagasri, M.L.; Sridhar, M.; Raju, K.P. Kriging-based ionospheric TEC, ROTI and amplitude scintillation index (S 4) maps for India. IET Radar Sonar Navig. 2020, 14, 1827-1836. [CrossRef]

72. Zhou, W.; Gu, S.; Ge, M.; Wang, J. Analysis of the Effect of the 06-09-2017 Solar Flare on GNSS Signal and Positioning Performance. In China Satellite Navigation Conference; Springer: Berlin/Heidelberg, Germany, 2018; pp. 555-569. 
73. Liu, X.; Yuan, Y.; Tan, B.; Li, M. Observational Analysis of Variation Characteristics of GPS-Based TEC Fluctuation over China. ISPRS Int. J. Geo-Inf. 2016, 5, 237. [CrossRef]

74. Alkan, R.M.; Erol, S.; Ozulu, I.M.; Ilci, V. Accuracy comparison of post-processed PPP and real-time absolute positioning techniques. Geomat. Nat. Hazards Risk 2020, 11, 178-190. [CrossRef]

75. Nose, M.; Iyemori, T.; Sugiura, M.; Kamei, T. Geomagnetic Dst index. World Data Cent. Geomagn. Kyoto 2015, 10, 15-31. [CrossRef]

76. Matzka, J.; Bronkalla, O.; Tornow, K.; Elger, K.; Stolle, C. Geomagnetic Kp index. V. 1.0, GFZ Data Services, 2021. Available online: https://dataservices.gfz-potsdam.de/panmetaworks/showshort.php?id=escidoc:5216888 (accessed on 3 December 2021).

77. Kotulak, K.; Krankowski, A.; Froń, A.; Flisek, P.; Wang, N.; Li, Z.; Błaszkiewicz, L. Sub-Auroral and Mid-Latitude GNSS ROTI Performance during Solar Cycle 24 Geomagnetic Disturbed Periods: Towards Storm's Early Sensing. Sensors 2021, $21,4325$. [CrossRef] [PubMed]

78. Kotulak, K.; Zakharenkova, I.; Krankowski, A.; Cherniak, I.; Wang, N.; Fron, A. Climatology Characteristics of Ionospheric Irregularities Described with GNSS ROTI. Remote Sens. 2020, 12, 2634. [CrossRef]

79. Katsigianni, G.; Loyer, S.; Perosanz, F. PPP and PPP-AR Kinematic Post-Processed Performance of GPS-Only, Galileo-Only and Multi-GNSS. Remote Sens. 2019, 11, 2477. [CrossRef] 